\title{
-Snežana Kalamković
}

ISSN 0353-295X (Tisak) ISSN 1849-0344 (Online)

Radovi - Zavod za hrvatsku povijest

Vol. 46, Zagreb 2014
UDK 904:728>(497.5 Hrtkovci) (091)

stručni rad

kalamkovic@gmail.com

DOI: 10.17234/RadoviZHP.46.1

\section{Hrtkovci, lokalitet Vranj, opeka iz kasne antike}

\begin{abstract}
U ovom radu daje se prikaz arheološkog lokaliteta Hrtkovci-Vranj. Opisana je opeka s arheološkog lokaliteta Hrtkovci-Vranj i prikazani su i analizirani rezultati mikroskopskih snimaka i SEM i EDS analiza opeke i vezivnog materijala spomenutog arheološkog lokaliteta. Cilj rada je prikaz arheološkog lokaliteta Hrtkovci-Vranj iz kuta povjesničara kemije, pri čemu se želi napraviti spona između povjesničara, arheologa, restauratora, konzervatora i drugih vrsnih stručnjaka. Riječ je o tome da znanstvenici još nemaju jasnu sliku i pouzdane informacije u vezi s proizvodnjom opeke $u$ antici. Uzorak opeke je zrnaste strukture, koja ne pokazuje velike inhomogenosti, ali nema ni geometrijsko pravilo u rasporedu čestica. Pri većem uvećanju uočavaju se krupniji komadi kvarca i drugih minerala silikatnog sastava, koji po sastavu nisu karbonati, osim jednog minornog dijela. Moguće je da je lomljena opeka služila za bolje vezivanje cijelih opeka. Potvrda o pogodnosti građevinskog materijala za zidanje stambenog objekta, koji je ugrađen u vilu rustiku Hrtkovci-Vranj, snimak je rađen elektronskom mikroskopijom. $\mathrm{Na}$ temelju SEM i EDS rezultata, analitičari bi mogli izvesti zaključak o kemijskom sastavu opeke i vezivnog materijala na ispitanom lokalitetu. Na temelju poznavanja svojstava tih spojeva, temperature potrebne za njihovo stvaranje, tehnolozi bi mogli doći do zaključka koje gorivo je korišteno u pećima prilikom pečenja opeka. Na temelju nekadašnjeg izgleda terena i poznavanja istog, geolozi i stručnjaci iz zemljopisa mogu doći do zaključka potječe li gorivo s opisanog lokaliteta. Usporednom analizom sastava lokalnog zemljišta i sastava opeke, kao i usporednom rezultatima analiza opeka s arheoloških lokaliteta sličnog vremenskog doba, može se zaključiti je li opeka pravljena na licu mjesta. Cijeli rad je case study i njegova korisnost, upravo je u postavljanju temelja za daljnja istraživanja. Usporednom analizom kemijskog sastava opeka s drugih poznatih arheoloških lokaliteta može se zaključiti je li tehnologija proizvodnje bila slična i vjerojatno se može dokazati da proizvodnja opeke u kasnoj antici nadilazi okvire zanatske vještine i da se, na teritoriju rimske imperije, pojavila vojna inženjerija, koja je proizvodila keramičku robu s elementima tehnologije.
\end{abstract}

\section{Uvod}

Utjecaj Rimskog Carstva, u doba antike, na stanovništvo koje je boravilo na teritoriju Panonije je bilo značajno. Stanovništvo je živjelo sličnim načinom života kojim se živjelo i u središnjem dijelu Rimskog Carstva. Vrijedila su slična povijesna i društvena pravila. Način poljoprivredne proizvodnje, način pripreme kemijskih proizvoda, način prehrane, način odijevanja, izrada ogledala, ukrasnih predmeta, mozaika, keramičkih posuda i predmeta od stakla, preslika je vladajućih prilika. Arheološkim iskopavanjima, na lokalitetima drevnih rimskih hramova, 
pronađeni su kalupi za proizvodnju opeke i zidnih oranamenata, kao i peći za pečenje opeke i terakote. Smatra se da se proces vrlo malo razlikovao od današnjeg modeliranja, sušenja, pečenja. ${ }^{1}$

Današnji Srijem je u kasno doba Rimskog Carstva činio glavninu jedne od najvažnijih pograničnih rimskih pokrajina, sa Sirmijem (današnja Sremska Mitrovica) kao središtem. Na teritoriju Rume kojem administrativno pripadaju Hrtkovci nije se tada nalazilo neko veće selo, ali je zato konstatirano više poljoprivrednih imanja, tzv. villae rusticae. ${ }^{2}$ Dosadašnji su radovi o arheološkom lokalitetu Hrtkovci-Vranj uglavnom imali samo povijesnu konotaciju. Ovaj rad je drugačiji i pokušat će, na interdisciplinaran način, napraviti sponu između povijesti, povijesti kemije, analitičke kemije, arheologije i arhitekture.

\section{Hrtkovci}

Arheološki lokalitet Hrtkovci je mnogo puta opisan u eminentnim radovima (Slika 1.). ${ }^{3}$ Kad se prvi put u povijesti i pod kojim imenom javljaju Hrtkovci teško je pouzdano utvrditi. Ovo je vjerojatno najstarije naseljeno mjesto u općini Ruma, o čemu svjedoči arheološko nalazište s obližnjeg uzvišenja Gomolava, koje je jedno od najpoznatijih nalazišta iz vremena neolitika. Hrtkovci se kao rimsko-provincijalno naselje ne može po svojoj veličini i značaju usporediti s većim urbanim centrima u Panoniji, ali činjenice pokazuju da su u blizini Hrtkovaca živjeli Rimljani. ${ }^{4}$ Velikom seobom germanskih, hunskih, avarskih i slavenskih naroda (III. st.) uništena je i zaboravu prepuštena rimska kultura.

Dioklecijan je, provodeći 297. novi administrativni ustroj države, podijelio cijelu Panoniju na četiri područja. Gornju Panoniju podijelio je na Savsku Panoniju (Pannonia Savia ili Pannonia Ripariensis ili Pannonia Interamnensis) sa sjedištem u Sisciji (Siscia, danas Sisak) i na Prvu Panoniju (Pannonia Prima ili Pannonia Superior) sa sjedištem u Savariji (Savaria, danas Szombathely). Donju Panoniju podijelio je na Drugu Panoniju (Pannonia Secunda ili Pannonia Inferior ili Pannonia Sirmiensis) sa središtem u Sirmiju (Sirmium, danas Sremska Mitrovica) i na Panoniju Valeriju (Pannonia Valeria) sa sjedištem u Sopijani (Sopianae, danas Pečuh). ${ }^{5}$

\footnotetext{
1 ADAM 2005: 104-142, 265, 289-315, 336-338, 447, 540, 550, 604, 667, BOŠKOV, 2004. CAMPBELL 2004: 13-78, KURZMANN 2005: 405-414.

2 BOŠKOVIĆ 2011.

3 DAUTOVA-RUŠEVLJAN 1980: 146-153, DAUTOVA-RUŠEVLJAN 1982-1983: 47-49, DAUTOVA RUŠEVLJAN 1991: 41-62, DAUTOVA-RUŠEVLJAN I O. BRUKNER 1992, DAUTOVA-RUŠEVLJAN 1993: 53-70, DAUTOVA-RUŠEVLJAN 1999-2000a: 15-28, DAUTOVA-RUŠEVLJAN 1999-2000b: 163-174, DAUTOVA-RUŠEVLJAN 2005a: 239-249, DUATOVA-RUŠEVLJAN 2008: 257-312, O. BRUKNER 1981.

4 B. BRUKNER 1974.

5 GRAČANIN 2011: 49-50.
} 


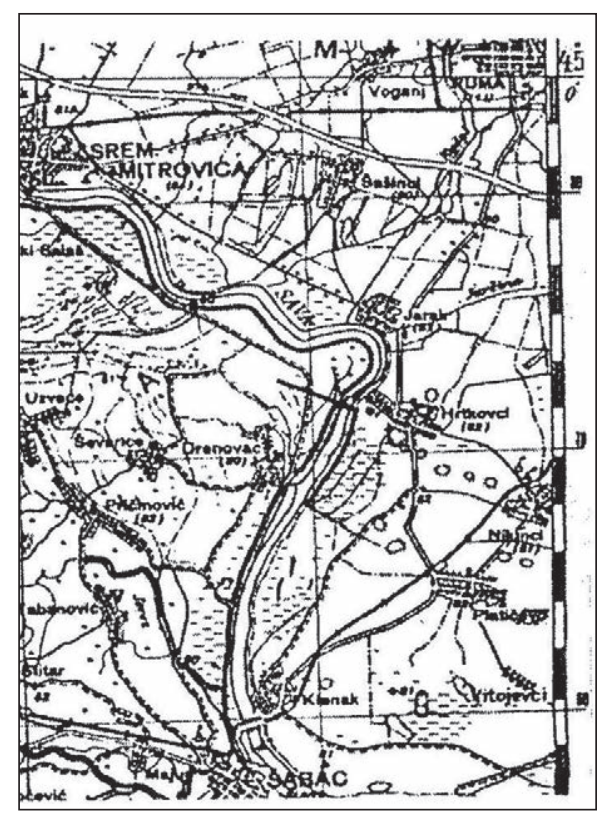

Slika 1. Topografski položaj vile u Hrtkovcima

Figure 1. Topographic Location Of The Villa In Hrtkovci ${ }^{3}$

Posljednji sloj na Gomolavi datira iz vremena rimske vladavine ovim prostorima i čine ga rimska vila rustika (villa rustica) s nekropolom (veliko groblje izvan naselja) (Slika 2.).

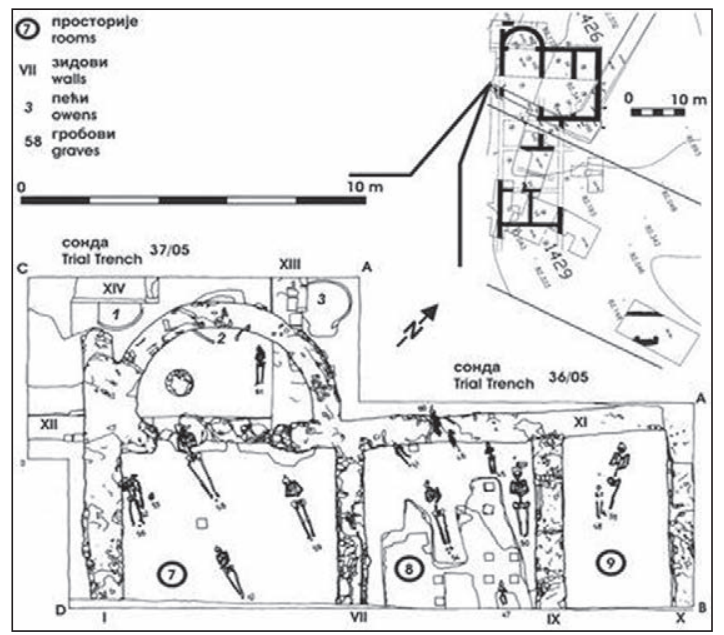

Slika 2. Vranj-Hrtkovci: Plan osnove novootkrivenog zapadnog dijela vile.

U manjem okviru: plan vile

Figure 2. Vranj-Hrtkovci: Plan showing the newly discovered western part of villa. Inset: plan of villa ${ }^{3}$ 
Vila rustika predstavlja veliku rimsku kuću izvan grada i nalazila su na velikom imanju, tj. zemljišnom posjedu (Slika 3.). Sastojala se od nekoliko dijelova: manjeg i raskošnog dijela namijenjenog upravitelju ili gospodaru imanja; dijela namijenjenog nadzornicima radova; velikih prostorija za smještaj sluga. Arhitektonski ostaci velikog poljoprivrednog imanja djelomično su ispitani. ${ }^{6}$

Analizama je dokazano da zidovi zgrada sadrže kamen, opeku sivo-bijele boje debljine $0,5 \mathrm{~m}$, ali i lomljenu opeku. Ostaci podova, u svakoj sobi zgrade, su 0,50$0,75 \mathrm{~m}$ dubine. Iskopani su fragmenti freske od keramičkih pločica, crvene boje na bijeloj podlozi, fragmenti keramike, stakleno posuđe, predmeti od bronce i željeza i kosti. Veličina zgrade, veći broj soba, ali i kanalizacijska mreža i sustav za grijanje, ukazuju da je vlasnik bio bogat. Područje je, često, bilo meta napada barbara. ${ }^{7}$

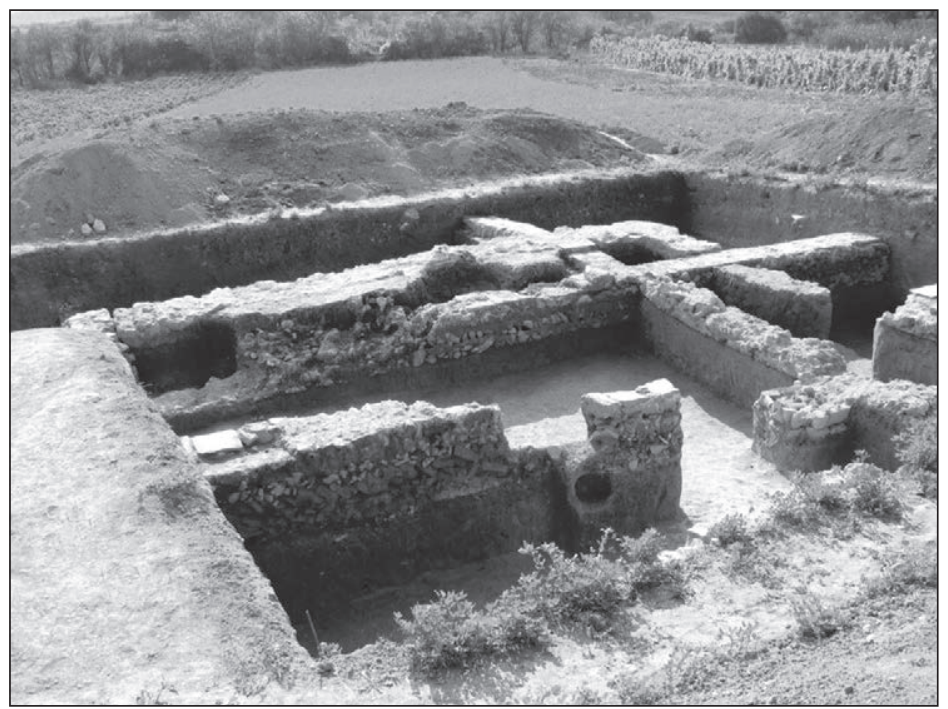

Slika 3. Zidovi i temelji jednog dijela vile rustike iz III i IV stoljeća, iskopavanje 2008., površina $100 \mathrm{~m}^{2}$, nepublikovanom materijal $0,44^{\circ} 52$ '44” S 0,19 ${ }^{\circ} 46^{\prime} 14^{\prime \prime}$ ' I

Figure 3. The walls and the foundations of one of the villa, the third and fourth centuries, excavation 2008., area $100 \mathrm{~m}^{2}$, unpublished material 0,44 '52 '44” $\mathrm{N} 0,19^{\circ} 46$ ' $14^{\prime \prime} \mathrm{E}$

Prema povijesnim spisima, rimske kuće su, često, bile ukrašene slikama na zidovima i mozaicima. Rimske kuće su građene od kamena i opeka. Bilježi se kontinuitet $\mathrm{u}$ razvoju materijalne kulture, $\mathrm{s}$ većom dinamikom i evidentnim utjecajem države, kao pravno-utemeljene zajednice (slobodnih) građana. Romanska kultura,

6 DAUTOVA-RUŠEVLJAN 1981: 181-201, DAUTOVA-RUŠEVLJAN 1998: 97-102, DAUTOVA-RUŠEVLJAN 1999: 54-65, DAUTOVA-RUŠEVLJAN I VUJOVIĆ 2006.

7 DAUTOVA-RUŠEVLJAN 1987: 90, DAUTOVA-RUŠEVLJAN 1995-1996: 53-75, DAUTOVA RUŠEVLJAN 2005b: 395-416, O. BRUKNER 1995: 147-148, BURGER 1966, KURZMANN 2005: 405-414. 
koja je absorbirala helensku i blisko-istučnu kulturu, stvorila je takav ambijent, čiji utjecaj se osjeća i dan-danas. Visoka razina proizvodnje, u kasnoj antici, postizan je dobrim poznavanjem robe i materijala, ali i znalačkom organizacijom procesa proizvodnje. Umješnost zanatlije nije bila dovoljna za društvenu proizvodnju, tj., za udovoljavanje potreba organizirane i kompaktne rimske države, već su se pojavili i stručnjaci, koji su mogli jamčiti, često i vrhunskim kvalitetu proizvoda. U kasnoj antici, na teritoriju rimske imperije, pojavila se vojna inženjerija, tj. rimske legije, koje su proizvodile keramičku robu s elementima tehnologije. ${ }^{8}$

Rekonstrukcija povijesnih zbivanja od kasne antike do ranog srednjeg vijeka i danas je težak i često nezahvalan posao. Jedan od razloga je nedostatak pisanih izvora, te kontradikcije ili nejasnoće u onim rijetkim povijesnim vrelima koja su sačuvana iz toga doba. ${ }^{9}$

\section{Opeka s arheološkog lokaliteta Hrtkovci-Vranj}

Po izgledu uzorka opeke s arheološkog lokaliteta Hrtkovci-Vranj, može se konstatirati prisutnost željeza i kvarcnog materijala (Slike 4. i 5.). Ioni željeza, koji su sastavni dijelovi opeke, karakteristične su crvene boje i velik je njihov postotak, pa je i opeka jače crvene boje, dok kvarcni materijal daje jednu nehomogenu strukturu, pa je građevinski materijal otporniji i pogodniji za zidanje zgrada $\mathrm{i}$ bedema. Fragmenti opeke bili su ostaci vile rustike nepoznatog vlasnika. Mjesto uzimanja cigle je odmah iznad kamenog temelja, visine 1-1,5 $\mathrm{m}$. Interesantno je da su drugi autori dolazili do rezultata da je opeka sivo-bijele boje debljine $0,5 \mathrm{~m}$, a da postoji i lomljena opeka. Prema rezultatima analiza, može se izvesti zaključak da je fragment opeke upravo lomljena opeka.

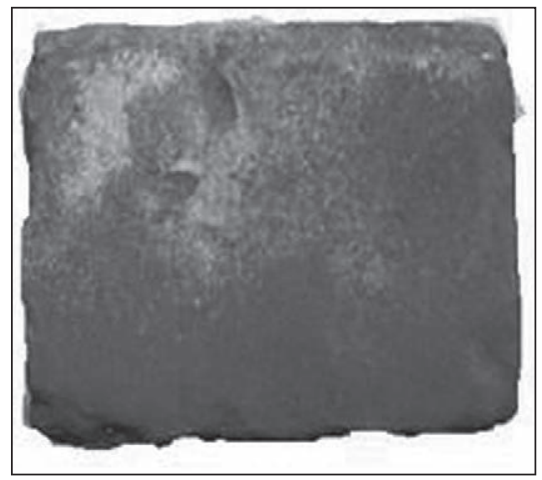

Slika 4. Uzorak opeke sa arheološkog lokaliteta Hrtkovci-Vranj

Figure 4. Sample bricks from the archaeological site Hrtkovci-Vranj

\footnotetext{
8 HALAŠI, KALAMKOVIĆ, ADAMOV, HALAŠI, SEGEDINAC 2007: 69-70.

9 GRAČANIN 2011: 9.
} 


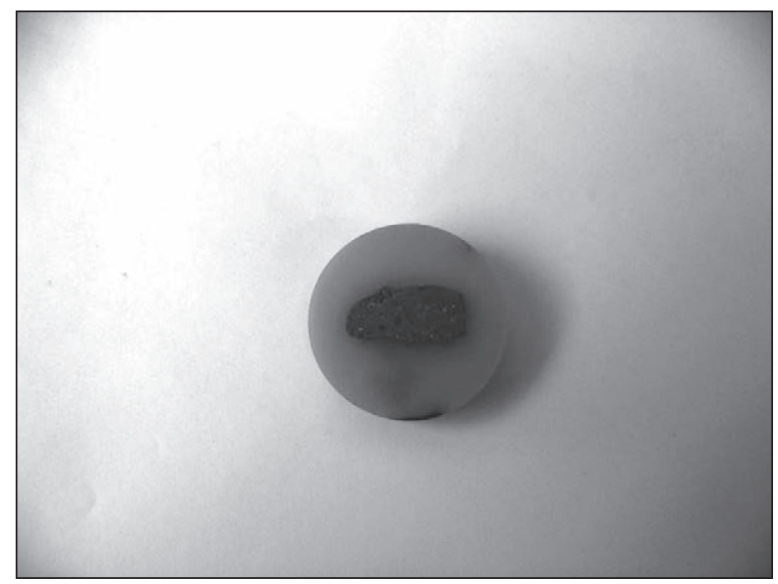

Slika 5. Uzorak opeke (kalup) sa arheološkog lokaliteta Hrtkovci-Vranj

Figure 5. Brick pattern (mold) from the archaeological site Hrtkovci-Vranj

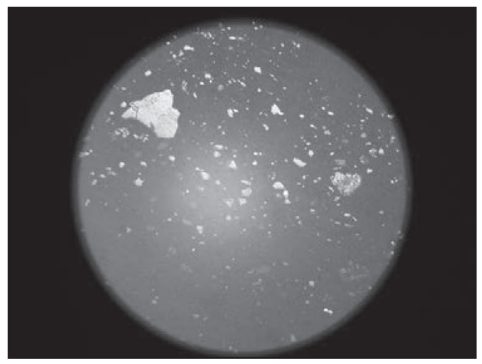

a)

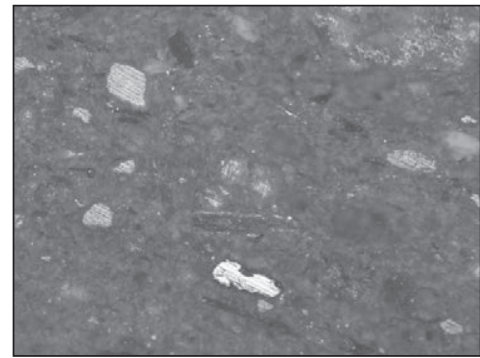

b)

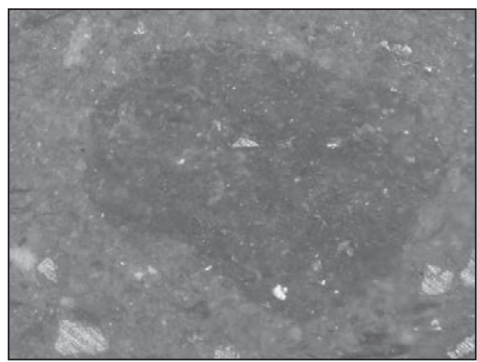

c)

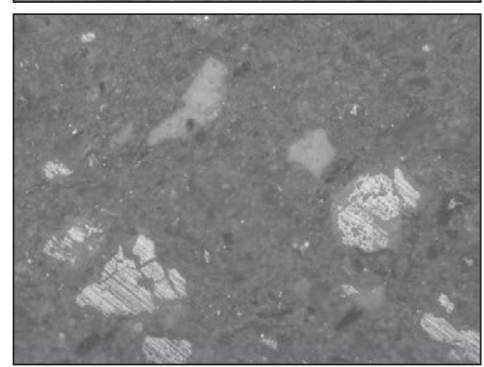

d)

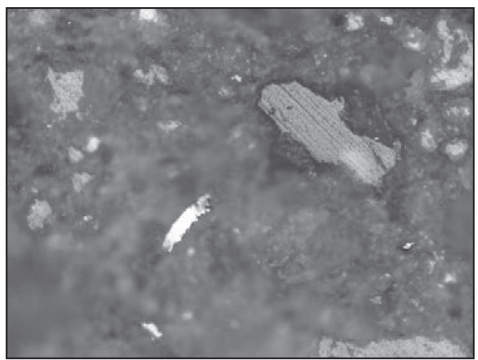

e)

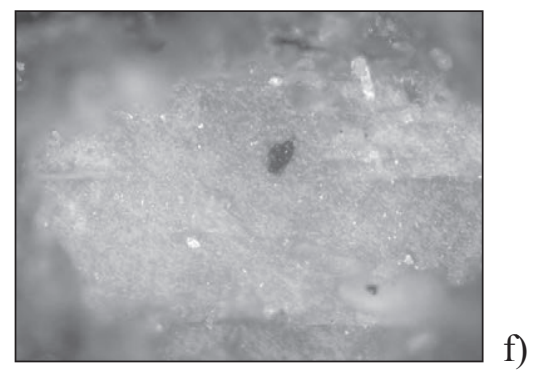

Slika 6. Mikroskopski snimci uzorka sa lokaliteta Hrtkovci-Vranj

Figure 6. Microscopic photographs of the site Hrtkovci-Vranj 
Mikroskopski snimci opeke pokazuju da je struktura umjereno nehomogena, što znači da je osnovna sirovina za izradu opeke bila crvena glina i kvarcni pijesak. Prema Slici 6. (a, b, c, d, e i f), uzorak je zrnaste strukture koja ne pokazuje velike inhomogenosti, ali nema ni geometrijsko pravilo u rasporedu čestica. Pri većem uvećanju uočavaju se krupniji komadi kvarca i drugih minerala silikatnog sastava, koji po sastavu nisu karbonati, osim jednog minornog dijela. Moguće je da je lomljena opeka služila za bolje vezivanje cijelih opeka. Analiza strukture opeke s arheološkog lokaliteta Hrtkovaca-Vranj vršena je uz pomoć rezultata i mikroskopskih slika arheoloških lokaliteta drugih dijelova svijeta, sličnog vremenskog razdoblja. Usporednom analizom hemijskih sastava ulomka opeke sa arheološkog lokaliteta Hrtkovci-Vranj i opeke s arheološkog lokaliteta Felix Romuliana, može se zaključiti da opeka s lokaliteta Hrtkovci-Vranj sadrži duplo više \% silicija od opeke s lokaliteta Felix Romuliana, dok je \% željeza u obrnutom odnosu. Koncentracija kalcija u uzorku Hrtkovci-Vranj je zanemariva. ${ }^{10}$ Potvrda o pogodnosti građevinskog materijala za zidanje stambenog objekta koji je ugrađen u vilu rustiku Hrtkovci-Vranj snimak je rađen elektronskom mikroskopijom. Ovo je potvrda konstatacije koja je dana pri optičko-mikroskopskoj analizi ovoga uzorka (Slika od 6. do 11., kao i Tablica 1. i 2.).

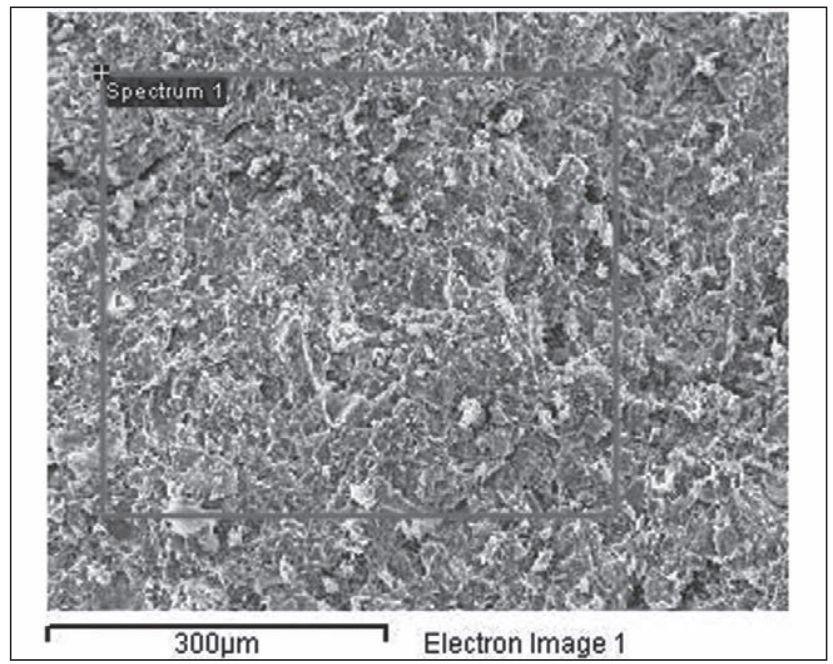

Slika 7. SEM opeke, Hrtkovci

Figure 7. SEM brick Hrtkovci

10 T. HALAŠI, KALAMKOVIĆ, R. HALAŠI. 2008, T. HALAŠI, KALAMKOVIĆ, RADULOVIĆ, MARK, R. HALAŠI, FOLIĆ. 2011: 66-67, T. HALAŠI, KALAMKOVIĆ, MANDIĆ. 2013, T. HALAŠI, KALAMKOVIĆ, MIKLOŠ, MANDIĆ. 2013, KALAMKOVIĆ, T. HALAŠI, UZELAC. 2014: 203-208 PAVIA. 2008: 201-218, PETROVIĆ, JOVANOV, VUJOVIĆ, RANOGAJEC, FIDANCEVSKA. 2007: 75-80. 


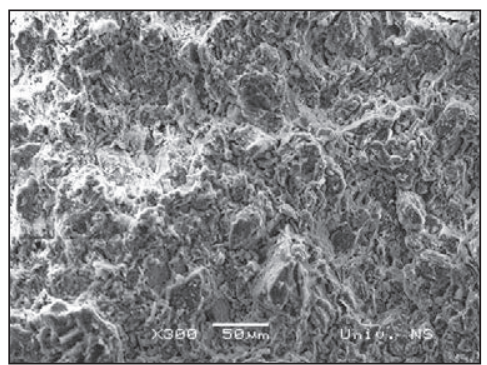

a)

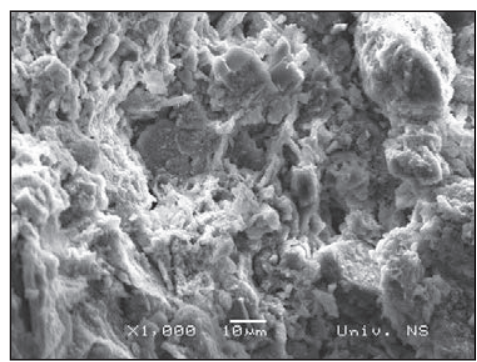

b)
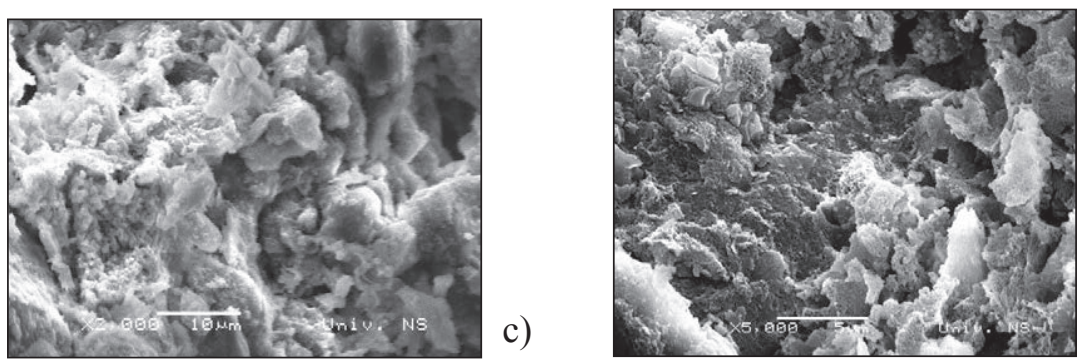

d)

Slika 8. SEM Hrtkovci opeka

Figure 8. SEM Hrtkovci brick

Kompletna analiza i komentar Slike 8. (a, b, v, g) je učinjen na temelju objavljenih radova stranih istraživača i pri uvećanju 300 (Slika 8a.) i pri uvećanju 1000 (Slika 8b.) i pri uvećanju 2000 (Slika 8c.) i pri uvećanju 5000 (Slika 8d.) uočava se ljuspasta struktura kvarca. ${ }^{11}$

Tabela 1. EDS analiza opeke, Hrtkovci (\%)

Table 1. EDS analysis of brick, Hrtkovci (\%)

\begin{tabular}{|l|c|c|c|c|c|c|c|c|c||c|c|c|}
\hline \hline Spectrum & In stats. & $\mathrm{O}$ & $\mathrm{Na}$ & $\mathrm{Mg}$ & $\mathrm{Al}$ & $\mathrm{Si}$ & $\mathrm{Cl}$ & $\mathrm{K}$ & $\mathrm{Ca}$ & $\mathrm{Ti}$ & $\mathrm{Fe}$ & Total \\
\hline Spectrum 1 & Yes & 55.11 & 0.52 & 1.67 & 8.74 & 24.15 & 0.34 & 1.77 & 1.46 & 0.56 & 5.70 & 100.00 \\
\hline Mean & & 55.11 & 0.52 & 1.67 & 8.74 & 24.15 & 0.34 & 1.77 & 1.46 & 0.56 & 5.70 & 100.00 \\
\hline
\end{tabular}

11 MERKEVIČIUS, BEZDICKA, JUŠKĖNAS, KIUBERIS, JŪRATĖ, PAKUTINSKIENĖ, KAREIVA 2007: 36-39. 


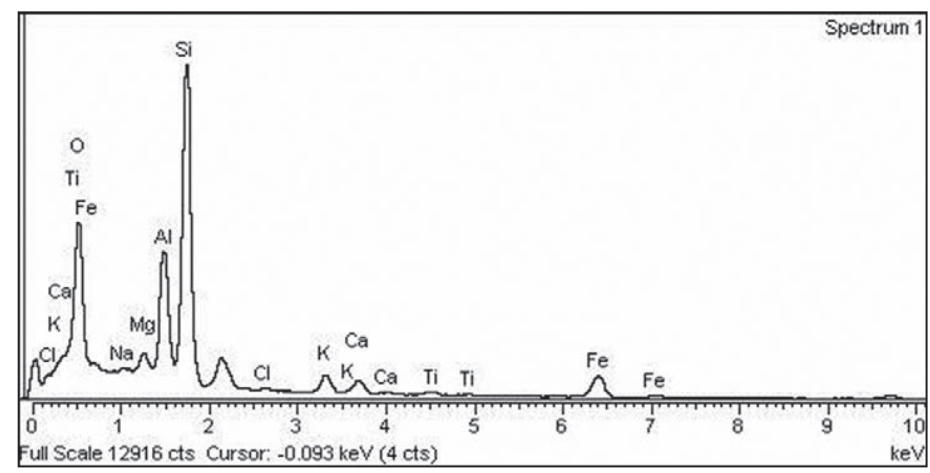

Slika 9. EDS opeke, Hrtkovci

Figure 9. EDS brick, Hrtkovci

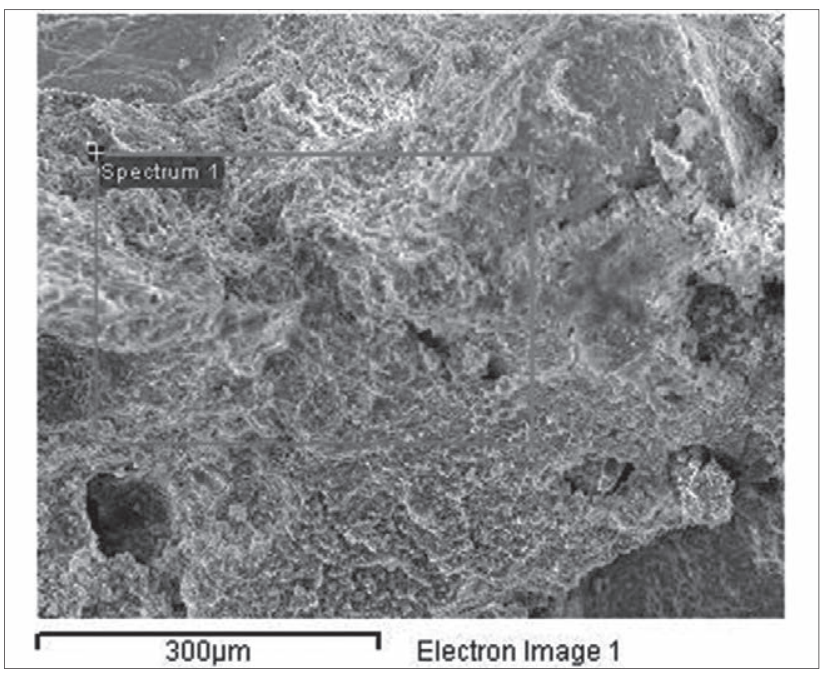

Slika 10. SEM vezivo, Hrtkovci

Figure 10. SEM binder, Hrtkovci

Tabela 2. EDS analiza vezivnog materijala, Hrtkovci (\%)

Table 2. EDS analysis of binder, Hrtkovci (\%)

\begin{tabular}{|l|c|c|c|c|c|c|c|c|c|c|}
\hline Spectrum & In stats. & $\mathrm{C}$ & $\mathrm{O}$ & $\mathrm{Mg}$ & $\mathrm{Al}$ & $\mathrm{Si}$ & $\mathrm{K}$ & $\mathrm{Ca}$ & $\mathrm{Fe}$ & Total \\
\hline Spectrum 1 & Yes & 20.91 & 49.86 & 0.62 & 0.93 & 5.33 & 0.23 & 21.43 & 0.70 & 100.00 \\
\hline \hline Mean & & 20.91 & 49.86 & 0.62 & 0.93 & 5.33 & 0.23 & 21.43 & 0.70 & 100.00 \\
\hline
\end{tabular}




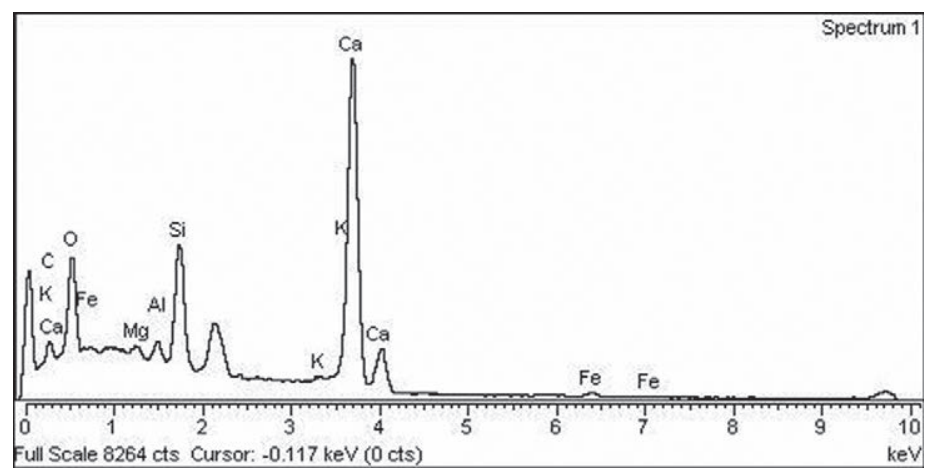

Slika 11. EDS vezivo, Hrtkovci

Figure 11. EDS binder, Hrtkovci

\section{Zaključak}

Analize su dovele do razumijevanja osnovnih fizičkih svojstava, mikrostrukture i mineraloškog i kemijskog sastava opeke na arheološkom lokalitetu Hrtkovci-Vranj. Sirovine koje su korištene za izradu su kalcij, siromašna glina, a temperaturama plamena je varirala od 550 do $900{ }^{\circ} \mathrm{C}$. Temperatura je zavisila od kvalitete goriva i od namjene opeke. Što je manja temperatura pečenja bila, to je opeka bila lošije kvalitete.

Današnji znanstvenici, još uvijek, nemaju jasnu sliku i pouzdane informacije $\mathrm{u}$ vezi s proizvodnjom opeke $\mathrm{u}$ antici. ${ }^{12}$ Zanimljivo je to da rimske opeke, koje datiraju od sredine I. stoljeća, imaju pečat ili trgovačku marku utisnute na samoj opeki. Ovi znakovi predstavljaju veliku kronološku i topografsku vrijednost, ali nam i otkrivaju s kojeg izvora potječe glina od koje je napravljena opeka, mjesto i datum izrade. Uzorak koji je analiziran u ovom radu je ulomak i nema oznaku.

Na temelju rezultata, mogao bi se izvesti zaključak o kemijskom sastavu opeke i vezivnog materijala na ispitanom lokalitetu. Na temelju poznavanja svojstava tih spojeva, temperature potrebne za njihovo stvaranje, moglo bi se doći do zaključka koje gorivo je korišteno u pećima prilikom pečenja opeka. Na temelju nekadašnjeg izgleda terena i njegova poznavanja, može se doći do zaključka potječe li gorivo sa opisanog lokaliteta. Usporednom analizom sastava lokalnog zemljišta i sastava opeke može se zaključiti je li opeka pravljena na licu mjesta. Usporednom analizom kemijskog sastava opeka s drugih poznatih arheoloških lokaliteta može se zaključiti je li tehnologija proizvodnje bila slična i vjerojatno

12 KURZMANN 2005: 405-414, ADAM 2005: 104-142, 265, 289-315, 336-338, 447, 540, 550, 604, 667, DIMITRIJEVIĆ 1967: 94-99, KURZMANN 2006. 
se može dokazati da proizvodnja opeke u kasnoj antici nadilazi okvire zanatske vještine i da se, na teritoriju rimske imperije, pojavila vojna inženjerija, koja je proizvodila keramičku robu s elementima tehnologije.,,Rezultati višegodišnjeg istraživanja sa obe strane poteza Vranj, gde je pored ostalog, ispitano više od dvadest keramičkih peći sa jamama za pripremu i odbacivanje materijala, upućuju na razvijenu zanatsku produkciju tokom 1. i 2. veka u okviru šire gradske teritorije Sirmijuma, zbog povoljnih uslova, kvaliteta ilovače i blizine Save za trgovinu i transport robe ka istoku i zapadu." 13

\section{Bibliografija}

\section{Literatura}

ADAM Jean-Pierr., 2005. Roman building, Materials and Techniques, prevod: Anthony Mathews, Roudledge, London and New York.

BOŠKOV Svetozar, 2004. Antička prošlost Vojvodine u radovima Rastislava Marića, magistarska teza, Filozofski fakultet, Novi Sad.

BOŠKOVIĆ, Đorđe. 2011. Ruma u prošlosti. Istorijski pregled. Ruma: Zavičajni muzej Ruma, Gradska biblioteka “Atanasije Stojković.

BRUKNER, Bogdan. 1974. Velika arheološka nalazišta u Srbiji. Beograd: Arheološki institut.

BRUKNER, Olga. 1981. Rimska keramika u jugoslovenskom delu provincije Donje Panonije. Beograd: Pokrajinski zavod za zaštitu spomenika kulture SAP Vojvodine.

BRUKNER, Olga. 1995. Rimska naselja i vile rustike. Arheološka istraživanja duž autoputa kroz Srem, XIII, ur. Vapa Z., 147-148. Novi Sad: Pokrajinski zavod za zaštitu spomenika kulture.

BURGER, Alice. 1966. The Late Roman Cemetery at Sâgvâr. Acta Archaeologica Academiae Scientiarum Hungaricae XVI-II/1-4: 99-234.

CAMPBELL, James W. 2004. Brick A World History, London: Thames \& Hudson.

DAUTOVA-RUŠEVLJAN, Velika. 1980. Ein germanisches Grab auf derr Fundort Vranja bei Hrtkovci in Syrmien. Archaeologia Jugoslavica XX-XXI: 146-153.

DAUTOVA-RUŠEVLJAN, V. 1981. Rezultati zaštitno-sondažnih iskopavanja na lokalitetu 'Vranja' kod Hrtkovaca u Sremu 1979. godine. Rad vojvođanskih muzeja 27: 181-201.

DAUTOVA-RUŠEVLJAN, V. 1982-1983. Novac sa iskopavanja rimskog naselja na lokalitetu Gomolava (1953-1978). Rad vojvođanskih muzeja 28: 47-49.

DAUTOVA-RUŠEVLJAN, V. 1987. Hrtkovci - Gomolova - Keramička peć sa lokaliteta Vranj, Arheološki pregled 27: 90.

DAUTOVA-RUŠEVLJAN, V. 1991. Sondažno zaštitna iskopavanja na lokalitetu Vranj kod Hrtkovaca u Sremu, 1980-1989. Rad vojvođanskih muzeja 33: 41-62.

13 DAUTOVA-RUŠEVLJAN 1999-2000: 15-28. 
DAUTOVA-RUŠEVLJAN, V. 1993. Zaštitno iskopavanje rimskog naselja u Hrtkovcima 1991 godine. Rad vojvođanskih muzeja 35: 53-70.

DAUTOVA-RUŠEVLJAN, V. 1995-1996. Prilog pročavanju rimske keramike sa pečatnim ornamentima iz Srema. Rad vojvođanskih muzeja 37-38: 53-75.

DAUTOVA-RUŠEVLJAN, V. 1998. Grob iz kasnoantičkog perioda sa lokaliteta VranjHrtkovci. Rad Muzeja Vojvodine 40: 97-102.

DAUTOVA-RUŠEVLJAN, V. 1999. Coinage of Viminacium from Hrtkovci iri Srem. Macedonian Numismatic Journal 3: 59-65.

DAUTOVA-RUŠEVLJAN, V. 1999-2000. Villa Rustica na lokalitetuu Vranj u Hrtkovcima. Rad muzeja Vojvodine 41-42: 15-28.

DAUTOVA-RUŠEVLJAN, V. 1999-2000. Sistematsko-zaštitna iskopavanja u Hrtkovcima. Glasnik Srpskog arheološkog društva 15-16: 163-174.

DAUTOVA-RUŠEVLJAN, V. 2005. Sistematsko-zaštitna iskopavanja vile rustike u Hrtkovcima 2004. godine. Glasnik Srpskog arheološkog društva, vol. 22, br. 21: 239-249.

DAUTOVA-RUŠEVLJAN, V. 2005. Importovane posude terra sigillata i panonska produkcija sa lokaliteta Vranj u Hrtkovcima, Srem. Zbornik Narodnog muzeja - serija: Arheologija, vol. 18, br. 1: 395-416.

DAUTOVA-RUŠEVLJAN, V. 2008. Sistematsko-zaštitna iskopavanja na lokalitetu Vranj u Hrtkovcima 2005-2006. godine. Glasnik Srpskog arheološkog društva, br. 24: 287-312.

DAUTOVA-RUŠEVLJAN, V., Olga BRUKNER. 1992. Gomolava - rimski period. Novi Sad: Vojvođanski muzej, Gomolava 3.

DAUTOVA-RUŠEVLJAN, V., Miroslav VUJOVIĆ. 2006. Rimska vojska u Sremu. Novi Sad: Muzej Vojvodine.

DIMITRIJEVIĆ, Dimitrije. 1967. Progar, SO Zemun, lokalitet 'Progarski vinogradi' rimsko nalazište sa ostacima ciglane 'Classis Flaviae Pannonicae'. Arheološki pregled, 9: 94-99.

GRAČANIN, Hrvoje. 2011. Južna Panonija u kasnoj antici i ranom srednjovjekovlju (od konca 4. do konca 11. stoljeća). Zagreb: Plejada.

HALAŠI Tibor, Snežana KALAMKOVIĆ, Roža HALAŠI. 2008. Archeomineralogical and Chrystalographical Analysis of Samples From Some Location in Serbia. XV Conference of the Serbian Crystalographic Society.

HALAŠI Tibor, Snežana KALAMKOVIĆ, Branka RADULOVIĆ, Mikloš MARK, Roža HALAŠI, Nađa FOLIĆ. 2011. Kristalna struktura građevinskog materijala značajnih rimskih građevina sa arheoloških lokaliteta Srbije, XVIII Konferencija Srpskog kristalografskog društva, U Kapor, Klisurić i Mađarević 2011: 66-67. Novi Sad: PMF, Departman za fiziku, Novi Sad, PMF Novi Sad, Pokrajinski sekretarijat za nauku i tehnološki razvoj, Ministrastvo prosvete i nauke Republike Srbije.

HALAŠI Tibor, Snežana KALAMKOVIĆ, Jelena MANDIĆ. 2013. Chemical Analysis of the Brick from Archaeological Site Mihajlovac-Clevora, ICOSEC, Beograd.

HALAŠI Tibor, Snežana KALAMKOVIĆ, Mark MIKLOŠ, Jelena MANDIĆ. 2013. A régészeti minták spekrometriás vizsgálata, 56. Magyar Spektrokémiai Vándorgyülés, Környezetbarát anyagok és technológiák, A támop-4.2.2.B-10/1-2010-0025 Tu- 
dományos képzés mühelyeinek támogatása címü projekt keretében megrendezésre kerülö, Pannon Egyetem Veszprém.

KALAMKOVIĆ Snežana, Tibor HALAŠI, Đorđe UZELAC. 2014. Hemijska analiza fasade gimnazije „Jovan Jovanović Zmaj” u Novom Sadu, Tehnika 2-Naše građevinarstvo 68 (2014) 2, LXIX, U Vukanović i Božić (Naše građevinarstvo) 2014: 203-208, Beograd: časopis Saveza inženjera i tehničara Srbije.

KURZMANN Renate. 2005. Soldier, Civilian and Military Brick Production. Oxford Journal of Arhaeology, 24 (4): 405-414.

KURZMANN, R. 2006. Roman Military Brick Stamps: A Comparison of Methodology, [British Archaeological Reports, International Series 1543]. Oxford: Archaeopress.

MERKEVIČIUS Algimantas, Petr BEZDICKA, Remigijus JUŠKĖNAS, Jonas KIUBERIS, Senvaitiené JŪRATÉ, Irma PAKUTINSKIENE், Aivaras KAREIVA. 2007. XRD and SEM characterization of archaeological findings excavated in Lithuania. Chemija, Vol. 18. No. 1. P: 36-39.

PAVIA, Sara. 2008. Determination of brick provenance and technology using analytical techniques from the physical sciences, Archaeometry 48: 201-218.

PETROVIĆ, Snežana, Vojo JOVANOV, Slavica VUJOVIĆ, Jonjaua RANOGAJEC, Emilija FIDANCEVSKA. 2007. Historical materials from the medieval fortress Bač, Processing and Application of Ceramics 1(1-2): 75-80.

\section{Hrtkovci, Site Vranj, a Brick from Late Antiquity}

This paper presents the archaeological site Hrtkovci-Vranj. A brick from the archaeological site of Hrtkovci-Vranj is described and results of microscopic images and SEM and EDS analyse of bricks and connective material from the mentioned archaeological site are presented and analyzed. The goal is to present the archaeological site Hrtkovci-Vranj from the point of Vipn of historians of chemistry, so a link can be made between historians, archaeologists, restorers, conservators and other skilled professionals. A sample is grain structured, doesn't show great inhomogenities, but there is no rule in the geometric arrangement of the particles. At higher magnification are noticeable larger pieces of quartz and other silicate mineral composition, which are composed by carbonates, except for one minor part. It is possible that the broken bricks were used for better binding of the whole bricks. Confirmation of the benefits of building materials for masonry residential building, which is embedded in a villa rustica Hrtkovci-Vranj, is the recording that was made by electron microscopy. Analyses have shown that the walls of buildings contain stone, brick gray-white coloured thickness $0.5 \mathrm{~m}$, and broken bricks. Remains of floors in each room of the building were 0.50 to 0.75 $\mathrm{m}$ depth. From the appearance of the sample blocks from the archaeological site Hrtkovci-Vranj, we can conclude the presence of iron and silica materials. Based 
on the results, a conclusion can be made about the chemical composition of the bricks and binder. Based on the knowledge of the properties of these compounds, the temperature required for their creation, one might come to the conclusion which fuel was used in kilns during firing bricks. Based on the knoledge of the terrain it can be concluded wheater the fuel comes from that location. By comparing the results we can see if the brick was made on the spot. Parallel analysis of the chemical composition of bricks with other known archaeological sites it can be concluded if the production technology was similar. It can probably be demonstrated that the production of bricks in late antiquity goes beyond the scope of handicraft skills to the point where it had elements of technology.

Key words: archaeological site Hrtkovci-Vranj, microscopic shots, SEM, EDS.

Ključne riječi: arheološki lokalitet Hrtkovci-Vranj, mikroskopski snimci, SEM, EDS. 


\section{FILOZOFSKI FAKULTET SVEUČILIŠTA U ZAGREBU \\ ZAVOD ZA HRVATSKU POVIJEST \\ INSTITUTE OF CROATIAN HISTORY \\ INSTITUT FÜR KROATISCHE GESCHICHTE}

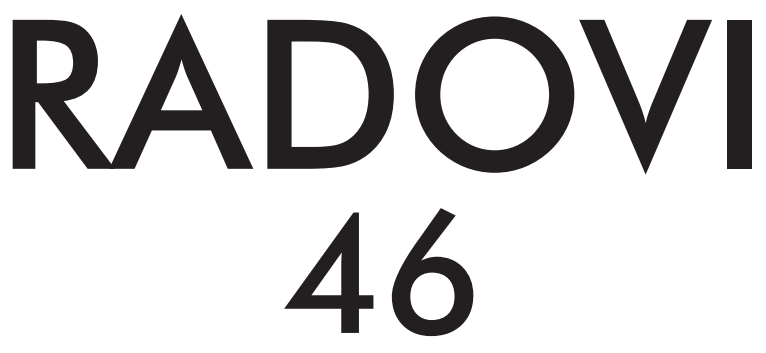

ZAVOD ZA HRVATSKU POVIJEST

FILOZOFSKOGA FAKULTETA SVEUČILIŠTA U ZAGREBU

FF press

ZAGREB 2014. 


\title{
RADOVI ZAVODA ZA HRVATSKU POVIJEST FILOZOFSKOGA FAKULTETA SVEUČILIŠTA U ZAGREBU
}

\author{
Knjiga 46 \\ Izdavač / Publisher \\ Zavod za hrvatsku povijest \\ Filozofskoga fakulteta Sveučilišta u Zagrebu \\ FF-press \\ Za izdavača / For Publisher \\ Vlatko Previšić \\ Glavni urednik / Editor-in-Chief \\ Hrvoje Gračanin \\ Uredništvo / Editorial Board
}

Bruna Kuntić-Makvić (stara povijest/ancient history), Zrinka Nikolić Jakus (srednji vijek/ medieval history), Hrvoje Petrić (rani novi vijek/early modern history), Željko Holjevac (moderna povijest/modern history), Tvrtko Jakovina (suvremena povijest/contemporary history),

Silvija Pisk (mikrohistorija i zavičajna povijest/microhistory and local history),

Zrinka Blažević (teorija i metodologija povijesti/theory and methodology of history)

Međunarodno uredničko vijeće / International Editorial Board

Denis Alimov (Sankt Peterburg), Živko Andrijašević (Nikšić), Csaba Békés (Budapest), Rajko

Bratož (Ljubljana), Snježana Buzov (Columbus, Ohio), Svetlozar Eldarov (Sofija), Toni Filiposki

(Skopje), Aleksandar Fotić (Beograd), Alojz Ivanišević (Wien),

Egidio Ivetić (Padova), Husnija Kamberović (Sarajevo), Karl Kaser (Graz),

Irina Ognyanova (Sofija), Géza Pálffy (Budapest), Ioan-Aurel Pop (Cluj),

Nada Proeva (Skopje), Alexios Savvides (Kalamata), Vlada Stanković (Beograd),

Ludwig Steindorff (Kiel), Peter Štih (Ljubljana)

\section{Izvršna urednica za tuzemnu i inozemnu razmjenu / \\ Executive Editor for Publications Exchange \\ Kristina Milković}

Tajnik uredništva / Editorial Board Assistant
Dejan Zadro

Adresa uredništva/Editorial Board address

Zavod za hrvatsku povijest, Filozofski fakultet Zagreb, Ivana Lučića 3, HR-10 000, Zagreb

Tel. ++385 (0)1 6120150,6120158 , faks ++385 (0)1 6156879

Časopis izlazi jedanput godišnje / The Journal is published once a year

Časopis je u digitalnom obliku dostupan na / The Journal in digital form is accessible at Portal znanstvenih časopisa Republike Hrvatske „Hrčak““ http://hrcak.srce.hr/radovi-zhp

Financijska potpora za tisak časopisa / The Journal is published with the support by Ministarstvo znanosti, obrazovanja i športa Republike Hrvatske,

Časopis je indeksiran u sljedećim bazama / The Journal is indexed in the following databases:

Directory of Open Access Journals, EBSCO, SCOPUS 
Naslovna stranica

Iva Mandić

Grafičko oblikovanje i računalni slog

Ivanka Cokol

\author{
Lektura \\ Jadranka Brnčić \\ Tisak \\ Web2tisak, Zagreb \\ Naklada \\ 250 primjeraka
}

Časopis je u digitalnom obliku dostupan na Portalu znanstvenih časopisa Republike Hrvatske „Hrčak“ http://hrcak.srce.hr/radovi-zhp

The Journal is accessible in digital form at the Hrcak - Portal of scientific journals of Croatia http://hrcak.srce.hr/radovi-zhp 